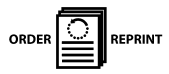

JOURNAL OF PLANT NUTRITION

Vol. 26, No. 6, pp. 1335-1343, 2003

\title{
Canopy Reduction and Legume Interseeding in Irrigated Continuous Corn ${ }^{\#}$
}

\author{
M. T. Humphreys, K. W. Freeman, R. W. Mullen, ${ }^{*}$ \\ D. A. Keahey, R. K. Teal, and W. R. Raun \\ Department of Plant and Soil Sciences, Oklahoma State University, \\ Stillwater, Oklahoma, USA
}

\begin{abstract}
Many alternative management systems have been evaluated for corn (Zea mays L.), soybeans (Glycine max L.), and wheat (Triticum aestivum L.) production, however, most have involved rotations from one year to the next. Legume interseeding systems which employ canopy reduction in corn have not been thoroughly evaluated. One such study was initiated in 1994 at the Panhandle Research Station near Goodwell, OK, on a Richfield clay loam soil, to evaluate five legume species interseeded into established corn: yellow sweet clover (Melilotus officinalis L.), subterranean clover (Trifolium subterraneum L.), alfalfa (Medicago sativa L.), arrowleaf clover (Trifolium vesiculosum L.), and crimson clover (Trifolium incarnatum L.). In addition, the effect of removing the corn canopy above the ear (canopy reduction) at physiological maturity was evaluated. Canopy
\end{abstract}

${ }^{\#}$ Contribution from the Oklahoma Agricultural Experiment Station.

*Correspondence: R. W. Mullen, Department of Plant and Soil Sciences, Oklahoma State University, 044 Agricultural Hall, Stillwater, OK 74078, USA; E-mail: wrr@ mail.pss.okstate.edu.

1335

DOI: $10.1081 /$ PLN-120020374

Copyright (C) 2003 by Marcel Dekker, Inc.
0190-4167 (Print); 1532-4087 (Online) www.dekker.com

MARCEL DeKKer, INC 270 Madison Avenue, New York, New York 10016 


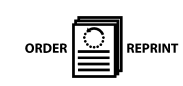

reduction increased light interception beneath the corn thus enhancing legume growth in late summer, early fall, and early spring the following year prior to planting. Forage growth from legumes incorporated prior to planting were expected to lower the amount of inorganic nitrogen $(\mathrm{N})$ fertilizer needed for corn production. Crimson clover appeared to be more shade tolerant than the other species, and interseeding this species resulted in the highest corn grain yields when no $\mathrm{N}$ was applied. In the last two years, interseeding crimson clover at physiological maturity, followed by canopy reduction resulted in a $1.32 \mathrm{Mg} \mathrm{ha}^{-1}$ increase in yield compared to conventionally grown corn with no $\mathrm{N}$ applied. In 1999, interseeded legumes (except subterranean clover) in conjunction with the application of $56 \mathrm{~kg} \mathrm{Nha}^{-1}$ and crimson clover interseeded without the addition of fertilizer $\mathrm{N}$ (with and without canopy reduction) resulted in grain $\mathrm{N}$ uptake levels equal to the $112 \mathrm{~kg} \mathrm{Nha}^{-1}$ treatment.

Key Words: Canopy reduction; Legume interseeding; Green manure; Alternative corn management systems.

\section{INTRODUCTION}

Canopy reduction has been used in third world countries as a means of increasing light interception for relay crops. Canopy reduction is defined as the removal of the corn canopy just above the ear at physiological maturity (when nutrient and water uptake has ceased), where the cut portion is allowed to drop to the soil surface. The basis of canopy reduction comes from regions where a relay crop like common bean (Phaseolus vulgaris L.) is produced following corn (Zea mays L.). Canopy reduction increases the chances of producing a bean crop that would not have been possible if planting took place following corn harvest, without sacrificing corn grain yield (Fig. 1).

Over the past 20 years, various researchers have evaluated intercropped legumes for increased nitrogen $(\mathrm{N})$ supply in corn production. As sources of inorganic $\mathrm{N}$ fertilizer become less dependable and prices increase, organic forms, particularly legumes, are being considered as alternative sources for non-legume crops. Searle ${ }^{[1]}$ stated that corn grain yield was not affected by legume intercrop, indicating neither competitive depression nor $\mathrm{N}$ transfer from the legume. Nair ${ }^{[2]}$ showed that intercropping corn with soybeans increased yield $19.5 \%$ when compared to monoculture corn. Scott ${ }^{[3]}$ noted that corn yield increases following medium red clover (Trifolium pratense L.) were equivalent to the addition of $17 \mathrm{~kg} \mathrm{ha}^{-1}$ fertilizer-N.

Even though intercropping usually includes a legume, applied $\mathrm{N}$ may still confer some benefits to the system as the cereal component depends heavily on 


\section{ORDER}

Canopy Reduction and Legume Interseeding

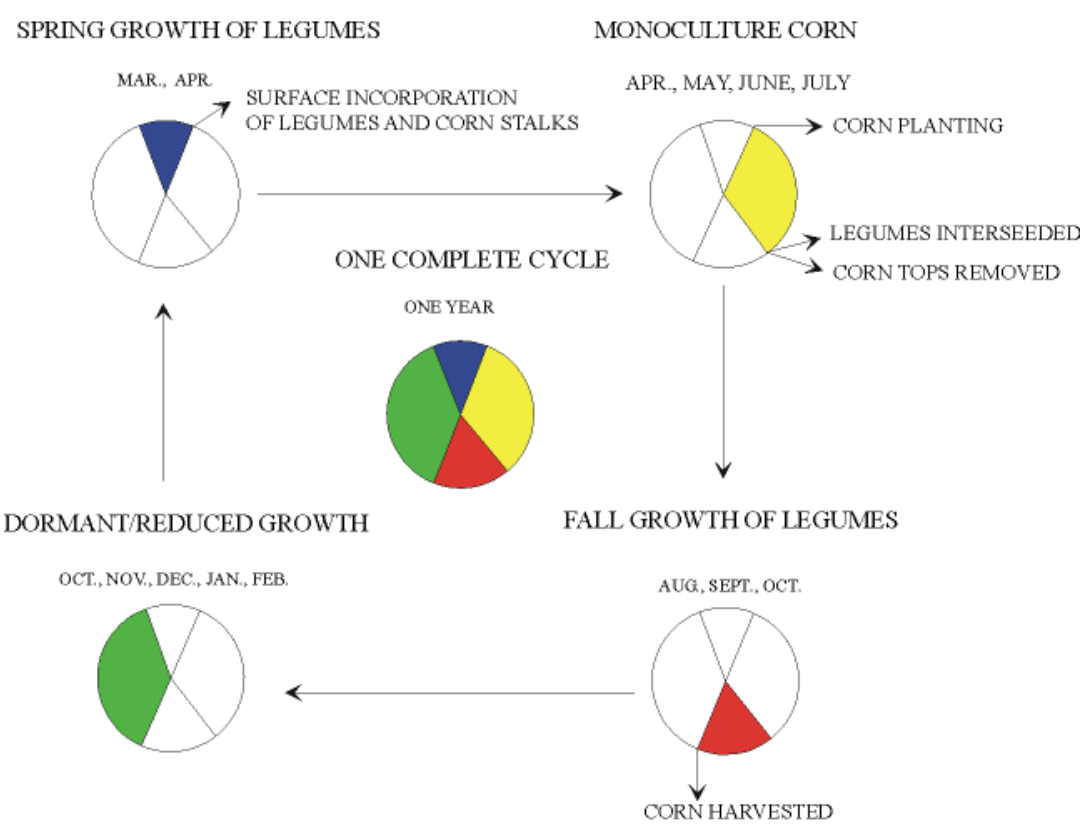

Figure 1. Time schedule for canopy reduction and legume interseeding.

$\mathrm{N}$ for maximum yield. ${ }^{[4]}$ Chowdhury and Rosario ${ }^{[5]}$ found that intercropping corn with mungbeans (Vigna radiata L.) increased yields $71 \%$ when the $\mathrm{N}$ application rate was increased from 0 to $90 \mathrm{~kg} \mathrm{ha}^{-1}$. Ebelhar ${ }^{[6]}$ reported with no fertilizer $\mathrm{N}$ applied, there was an increase in corn grain yield from 2.5 to $6.2 \mathrm{Mg} \mathrm{ha}^{-1}$ with hairy vetch (Vicia villosa L.) treatment compared with corn residue.

The objective of this work was to evaluate the effect of interseeded legume species and $\mathrm{N}$ rates combined with canopy reduction on corn grain yield and grain $\mathrm{N}$ uptake.

\section{MATERIALS AND METHODS}

One experiment was established in the spring of 1994 at the Oklahoma Panhandle Research and Extension Center near Goodwell, OK, on a Richfield clay loam (fine, montmorillonitic, mesic Aridic Argiustoll). Initial soil test characteristics and soil classification are reported in Table 1. A randomized complete block experimental design with three replications was employed. Plot size consisted of four rows $(76 \mathrm{~cm}) \times 7.6 \mathrm{~m}$. All treatments received 


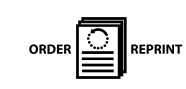

Table 1. Initial surface $(0-15 \mathrm{~cm})$ soil test characteristics and soil classification at Goodwell, OK.

\begin{tabular}{|c|c|c|c|c|c|c|c|}
\hline \multirow[b]{2}{*}{ Location } & \multirow[b]{2}{*}{$\mathrm{pH}$} & \multicolumn{2}{|c|}{$\left(\mathrm{g} \mathrm{kg}^{-1}\right)$} & \multicolumn{4}{|c|}{$\left(\mathrm{mg} \mathrm{kg}^{-1}\right)$} \\
\hline & & Total N & Organic C & $\mathrm{NH}_{4}-\mathrm{N}$ & $\mathrm{NO}_{3}-\mathrm{N}$ & $\mathrm{P}$ & $\mathrm{K}$ \\
\hline Goodwell & 7.7 & 1.4 & 11.7 & 65 & 25 & 29 & 580 \\
\hline
\end{tabular}

Note: $\mathrm{pH}, 1: 1$ soil: water; total $\mathrm{N}$ and organic $\mathrm{C}$, dry combustion; $\mathrm{NH}_{4}-\mathrm{N}$ and $\mathrm{NO}_{3}-\mathrm{N}, 2 \mathrm{M} \mathrm{KCl} ; \mathrm{P}$ and $\mathrm{K}$, Mehlich III.

$112 \mathrm{~kg} \mathrm{Nha}^{-1}$ of urea (45-0-0) in the fall of 1995 (Table 2). In 1996 and for the remaining years of this experiment, treatments $1-5,7$, and 12 received no $\mathrm{N}$ to assess legume $\mathrm{N}$ fixation compared to identical treatments with $56 \mathrm{~kg} \mathrm{ha}^{-1}$. Each year, corn was planted at a seeding rate of 182,780 seeds ha ${ }^{-1}$ between late April and early May and irrigated.

At physiological maturity, canopy reduction was imposed by removing the tops of the corn plants just above the ear using a machete (Fig. 2). This allowed sunlight to reach the legume seedbed. The tops were allowed to fall to the ground immediately following broadcast legume interseeding. In August, when the corn had reached physiological maturity (determined by periodic monitoring grain black layer formation), five legume species were interseeded by hand at the following seeding rates: yellow sweet clover (Melilotus officinalis L.) $44.8 \mathrm{~kg} \mathrm{ha}^{-1}$, subterranean clover (Trifolium subterraneum L.) $44.8 \mathrm{~kg} \mathrm{ha}^{-1}$, alfalfa (Medicago sativa L.) $33.6 \mathrm{~kg} \mathrm{ha}^{-1}$, arrowleaf clover (Trifolium vesiculosum L.) $22.4 \mathrm{~kg} \mathrm{ha}^{-1}$, and crimson clover (Trifolium incarnatum L.) $44.8 \mathrm{~kg} \mathrm{ha}^{-1}$. Following interseeding and canopy reduction, $5 \mathrm{~cm}$ of irrigation water was applied for legume establishment and to prevent reduction in growth caused by moisture stress. The legume seeds were inoculated prior to planting with a mixture of Rhizobium meliloti and Rhizobium trifolii bacteria. Harvest area consisted of two rows $\times 7.6 \mathrm{~m}$. Harvesting and shelling were performed by hand. Plot weights were recorded and sub-sampled for moisture and nutrient analysis. Subsamples were dried in a forced-air oven at $150^{\circ} \mathrm{F}$ and ground to pass a 140 -mesh screen. Total N concentration was determined on the 1997, 1998, 1999 grain samples using dry combustion. ${ }^{[7]}$ Nitrogen use efficiency was calculated using the difference method. ${ }^{[8]}$

Interseeded legumes remained in the field until the following spring when they were incorporated prior to corn planting using a shallow (4 inches) disk. Legumes were only used for ground cover and potential $\mathrm{N}$ fixation and as such were not harvested for seed or forage (Fig. 3). 


\section{ORDER}

Canopy Reduction and Legume Interseeding

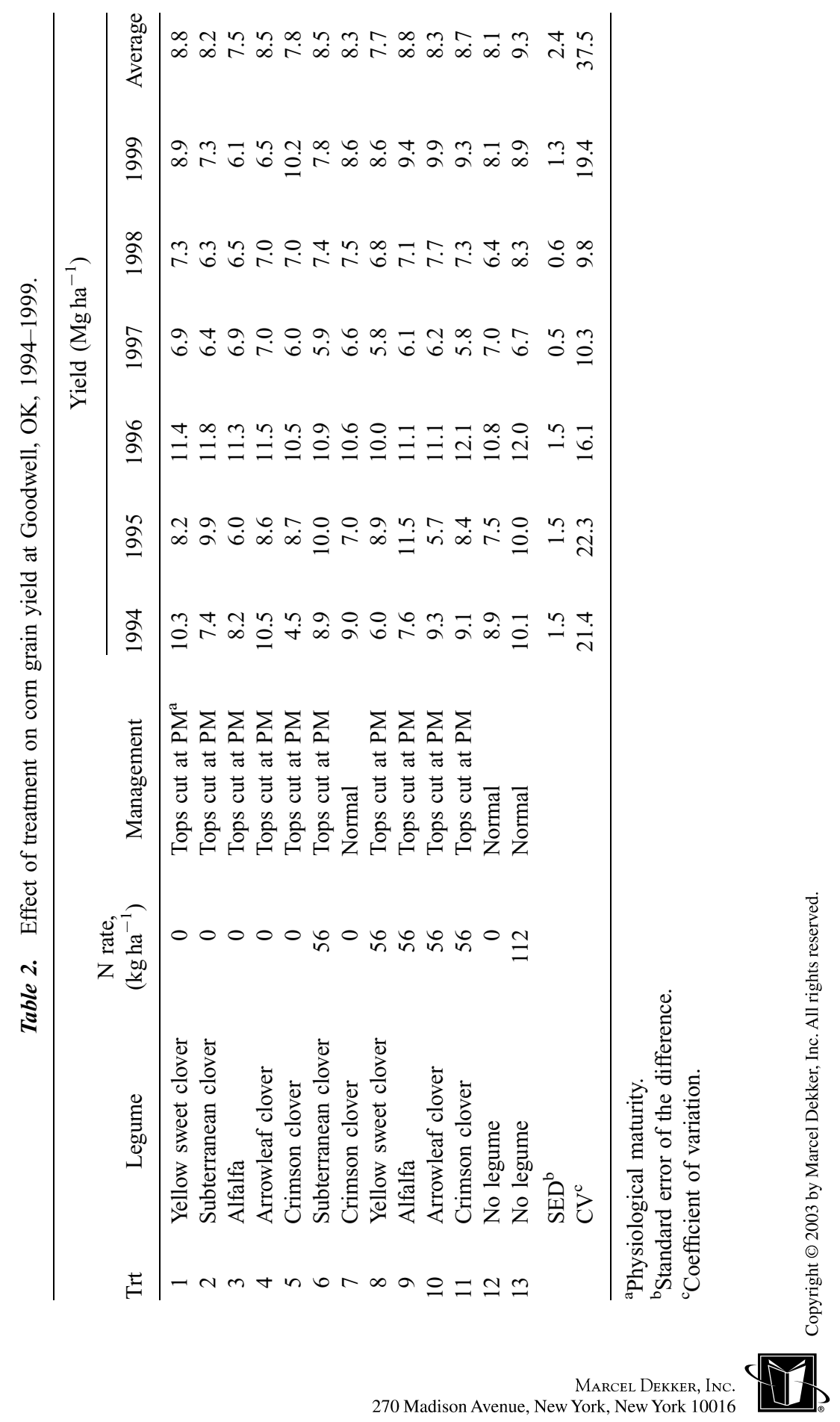



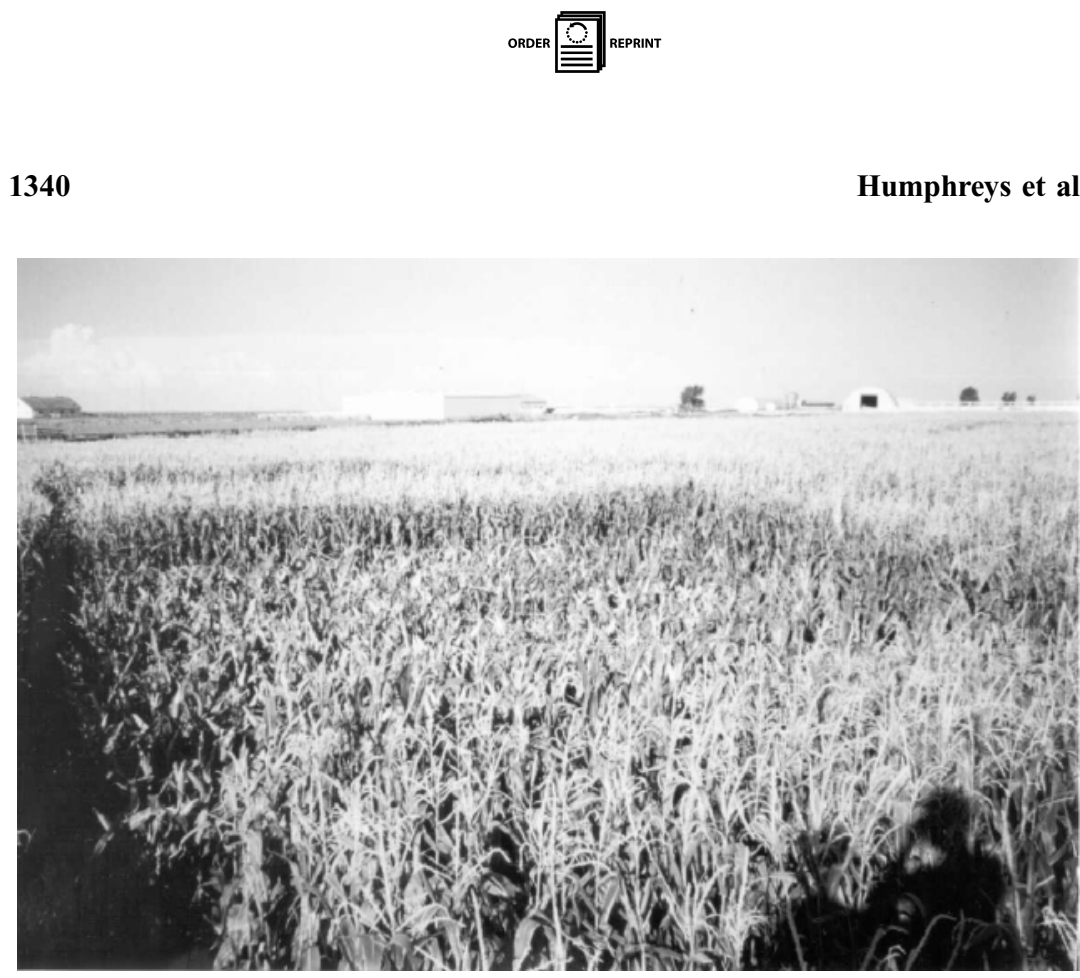

Figure 2. Canopy reduction imposed above the ear by means of a machete.

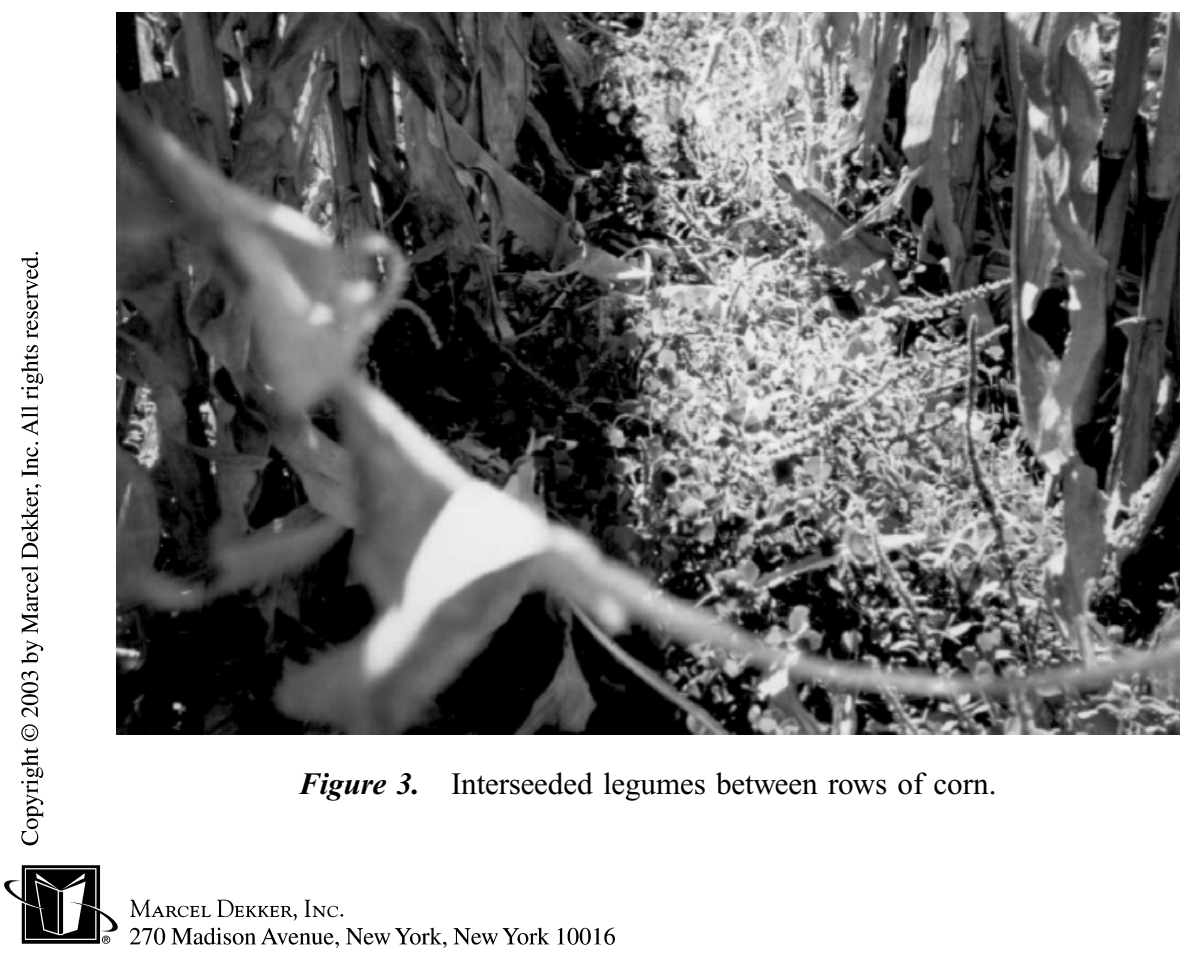




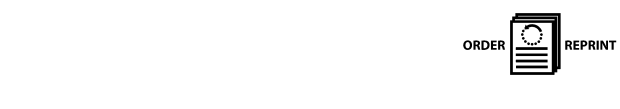

Canopy Reduction and Legume Interseeding

\section{RESULTS AND DISCUSSION}

\section{Grain Yield}

Canopy reduction enhanced legume growth in late summer, early fall before corn harvest, and early spring the following year prior to planting due to the increased amount of light let through the canopy. Crimson clover had superior spring growth compared to the other species evaluated as visual biomass production was greater when incorporated in early April prior to planting. No significant grain yield response to applied $\mathrm{N}$ was observed from 1994 to 1997 , but by 1998 , yields increased $1.95 \mathrm{Mg} \mathrm{ha}^{-1}$ as a result of applying N (12 vs. 13, Table 2$)$. The lack of fertilizer $\mathrm{N}$ response at this site restricted the early evaluation of legume $\mathrm{N}$ contribution and species comparison.

There was no significant difference between grain yields when tops were cut at physiological maturity compared to the normal practice ( 5 vs. 7 , crimson clover with and without canopy reduction, with no N applied) in 1996, 1997, or 1998. However, by 1999, interseeding crimson clover and using canopy reduction resulted in increased yields when compared to that observed where no canopy reduction was employed.

In the last two years of the study, interseeding crimson clover at physiological maturity, followed by canopy reduction resulted in an average yield increase of $1.35 \mathrm{Mg} \mathrm{ha}^{-1}$ when compared to conventionally grown corn with no $\mathrm{N}$ applied (5 vs. 12, Table 2). This yield increase with no $\mathrm{N}$ applied using crimson clover would be worth approximately $\$ 99 \mathrm{ha}^{-1}$ with corn grain worth $\$ 0.073 \mathrm{~kg}^{-1}$.

\section{Grain Nitrogen Uptake}

During the initial years of the experiment, treatment effects may have been masked by high inorganic N levels in the soil (Table 1). However, by 1998, interseeding of yellow sweet clover and crimson clover (with and without canopy reduction) without fertilizer $\mathrm{N}$ resulted in grain $\mathrm{N}$ uptake levels above the check and equal to corresponding legume interseeding with supplemental $\mathrm{N}$ (Table 3). In 1999, application of $56 \mathrm{~kg} \mathrm{Nha}^{-1}$ in conjunction with interseeding of a legume resulted in grain $\mathrm{N}$ uptake levels equal to that of the $112 \mathrm{~kg} \mathrm{Nha}^{-1}$ treatment with the exception of subterranean clover. Interseeding of crimson clover (with and without canopy reduction) without supplemental $\mathrm{N}$ also resulted in grain $\mathrm{N}$ uptake levels equal to the $112 \mathrm{~kg}$ $\mathrm{N} \mathrm{ha}^{-1}$ treatment.

Although not evaluated in this study, mechanized canopy reduction could decrease the time required for grain to lose moisture since more sunlight 6 


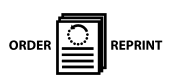

1342

Humphreys et al.

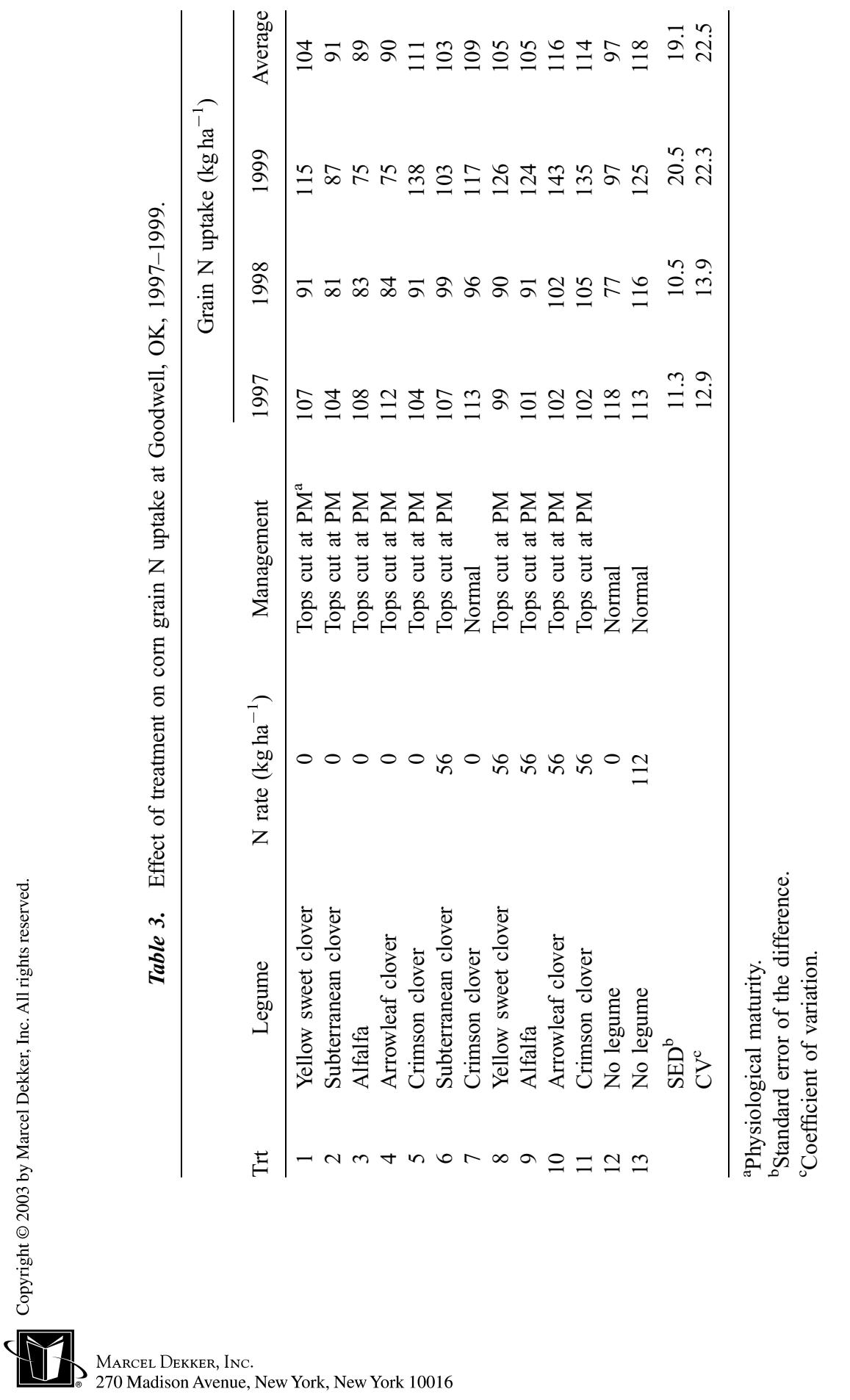




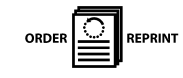

Canopy Reduction and Legume Interseeding

would directly come in contact with the corn ears when the tops were removed. When grain moisture is high it can delay harvest and/or significantly increase drying costs. Legume seeding rates, alternative species, method of interseeding, and interseeding date will all need to be thoroughly evaluated prior to the mechanization and implementation of this practice.

Since nitrate leaching and soil erosion are becoming major concerns in production agriculture today, this experiment may lead to practices that can decrease both, by lowering the amount of inorganic fertilizer $\mathrm{N}$ needed for corn production and reducing the amount of bare soil susceptible to wind and water erosion.

\section{REFERENCES}

1. Searle, P.G.E.; Comudom, Y.; Shedden, D.C.; Nance, R.A. Effect of maize + legume intercropping systems and fertilizer nitrogen on crop yields and residual nitrogen. Field Crops Res. 1981, 4, 133-145.

2. Nair, K.P.; Patel, U.K.; Singh, R.P.; Kaushik, M.K. Evaluation of legume intercropping in conservation of fertilizer nitrogen in maize culture. J. Agric. Sci., Cambridge 1979, 93, 189-194.

3. Scott, T.W.; Pleasant, J.M.; Burt, R.F.; Otis, D.J. Contributions of ground cover, dry matter, and nitrogen from intercrops and cover crops in a corn polyculture system. Agron. J. 1987, 79, 792-798.

4. Ofori, F.; Stern, W.R. Maize/cowpea intercrop system: effect of nitrogen fertilizer on productivity and efficiency. Field Crops Res. 1986, 14, 247-261.

5. Chowdhury, M.K.; Rosario, E.L. Comparison of nitrogen, phosphorus and potassium utilization efficiency in maize/mungbean intercropping. J. Agric. Sci., Cambridge 1994, 122, 193-199.

6. Ebelhar, S.A.; Frye, W.W.; Blevins, R.L. Nitrogen from legume cover crops for no-tillage corn. Agron. J. 1984, 76, 51-55.

7. Schepers, J.S.; Francis, D.D.; Thompson, M.T. Simultaneous determination of total C, total $\mathrm{N}$ and $15 \mathrm{~N}$ on soil and plant material. Commun. Soil Sci. Plant Anal. 1989, 20, 949-959.

8. Moll, R.H.; Kamprath, E.J.; Jackson, W.A. Analysis and interpretation of factors which contribute to efficiency of nitrogen utilization. Agron. J. 1982, 74, 562-564. 